\title{
Modified technology acceptance model for hospital information system evaluation - a case study
}

\author{
Vembri Noor Helia*, Vikha Indira Asri, Elisa Kusrini, and Suci Miranda \\ Department of Industrial Engineering, Universitas Islam Indonesia, Jl.Kaliurang km 14.5, Yogyakarta, Indonesia
}

\begin{abstract}
Hospital Information Systems (HIS) has been widely used in Indonesia. This implementation in hospital needs comprehensive, integrated information system designed to manage all the aspects of a hospital's operation. One of the factors that currently plays an important role in the successful HIS's application is the user factor. The hospital can evaluate HIS from user factor, so that it becoming better, perfect and can support the objectives, vision and mission of the hospital. This study aims to use the Modified Technology Acceptance Model created in Structural Equation Modeling (SEM) and tested using the software Amos 20 to determine the variables that most influence in HIS's application using in several hospitals in Sleman, Daerah Istimewa Yogyakarta Province, Indonesia. Data collected by distributing questionnaires to employees of D grade hospitals in Sleman district. The results from this study are seven variables that may influence the user in using HIS (Subjective Norm, Perceived Usefulness, Perceived Ease of Use, User Satisfaction, Behavior Intention to Use, Attitude Toward Using, Actual System Usage) and significant or insignificant relationship among them.
\end{abstract}

\section{Introduction}

Hospital Information Systems (HIS) has been widely used in Indonesia. Having HIS is a must for an accredited hospital. In the DIY province, $82.21 \%$ of all hospitals have adopted HIS [1]. The hospital information system has an important role in clinical and administrative services. There is evidence that there are use of information technology and individual performance at a hospital in Yogyakarta [2]. In addition, information technology is able to save filtering and processing the data into information with the higher capacity than manual methods.

Rapid technological development, making the information system as one determinant in the success of an organization's profit and non-profit. The information system has a role in supporting the operations, and supporting management in making decisions. HIS evaluation needs to be done because it can quantify the benefits from the use of such information systems [3]. The evaluation results can be used as a benchmark to improve or enhance HIS. So that, it becoming better, perfect and can support the objectives, vision and mission of the organization [4].

HIS evaluation can be done in various ways. HIS performance evaluation measurement model by looking at the relationship between the human-technologyorganization through HOT-Fit (Human-TechnologyOrganization-Net Benefit) [3, 4]. Before going into the organization, it needs evaluation from user acceptance. One way is using the Technology Acceptance Model
(TAM) to determine the acceptance of hospital admissions, such as in Bangkinang hospital [5], TAM with modifications to the doctor's private clinic [6], the reception HIS in hospital in Iran with seven variable [7]. TAM can also applicable to find the adoption of software measure with two variable, which are perceived usefulness and perceived ease of use [8].

Although many models have been proposed to explain and predict the use of the system, the Technology Acceptance Model has become the most public attention Information Systems method [9]. Therefore, in this study using the Modified Technology Acceptance Model to determine the variables that most influence in HIS that is suitable for use in several hospitals in Sleman, Daerah Istimewa Yogyakarta Province, Indonesia. It is more relevant and widely used in the literature, especially for the application of information technology in hospitals [10].

\section{Literature Review}

\subsection{Hospital Information System}

Hospital Management Information System is a system of information and communications technology that processes and integrates the entire workflow process Hospital services in the form of network coordination, reporting, and administrative procedures to obtain information appropriately and accurately and is part of the Health Information System [11]. This implementation

* Corresponding author: vembri@uii.ac.id 
needs comprehensive, integrated information system designed to manage all the aspects of a hospital's operation.

\subsection{Technology Acceptance Model (TAM)}

TAM was developed from a psychological theory that describes the behavior of computer users, which is based on belief, attitude, intention, and the relationship of user behavior (user behavior relationship). The purpose of this model is to explain the factors of user behavior on the acceptance of the use of technology.

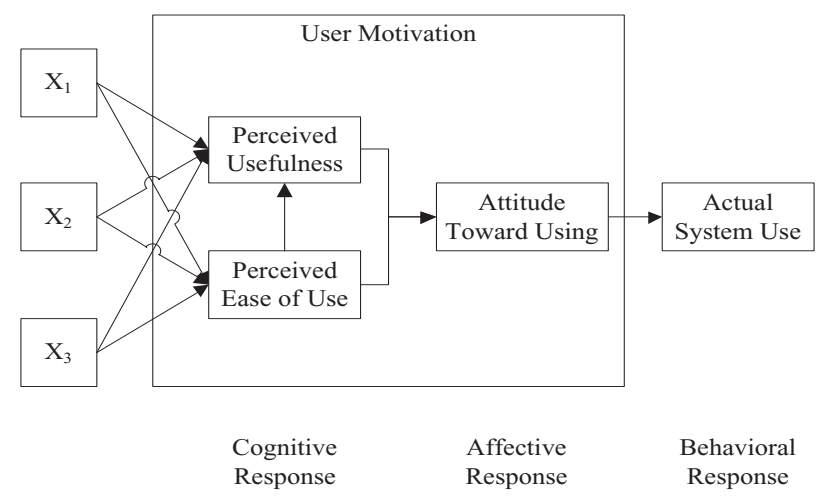

Fig 1. Technology Acceptance Model 1 [9]

Technology Acceptance Model is shown in Figure 1, with arrows represent causal relationships. Alternative systems are represented using a set of binary "design features" variable. According to the model, the overall attitude of potential users against using the system that is thought to be important determinants of whether he actually used it $[9,12]$.

TAM has many limitations in explaining the reasons for which a person can see a useful system, so it is necessary to add a few variables from previous studies [12]. The first modification is done by the Technology Acceptance Model additional external factors such as shown in Figure 2.

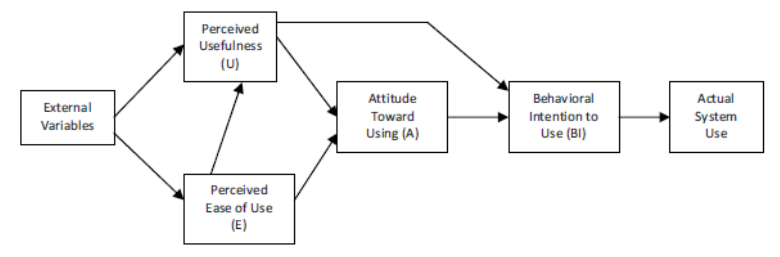

Fig 2. Technology Acceptance Model 2

There are studies which refer to the user and is used in hospitals as practiced in figure 3. Tabibi using a modified TAM with seven variables. The variables are Perceived Ease of Use (PEU), Perceived Usefulness (PU), Subjective Norms (SN), User Satisfaction (SAT), User Behavioral Intention (BI), Mandatoriness of system use (Mand) and System Use (USE).

\section{Methodology}

The research is to prove the hypothesis that built up with the approach of Modified Technology Acceptance Model (TAM) created in Structural Equation Modeling (SEM) and tested using the software Amos 20. Method of Modified TAM is able to analyze the factors that affect the user in using HIS at hospitals in Sleman. Data collected by distributing questionnaires to employees of D class hospital in Sleman district. The sample in this study was limited only to the medical nursing employee (outpatient, inpatient), medical non nursing (part laboratory, radiology, and pharmacy), and non-medical (part of medical records / registration, finance and accounting). Minimum number of samples in the study was 200 respondents.

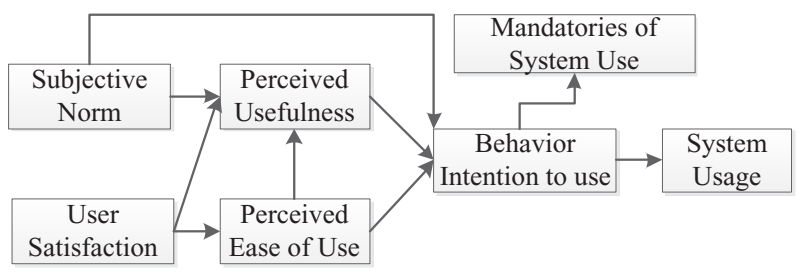

Fig 3. Modified Technology Acceptance Model for Hospital [7]

Questionnaires were administered to respondents referred to seven latent variables/constructs with 23 indicators. Variables Perceived Ease of Use (PEOU) has four indicators, which is easy to learn, easy to operate HIS, clear guidance on the use of HIS, supporting facilities provided by the hospital is adequate. Then, the variable Perceived Usefulness (PU) is to facilitate the task, the control for the work, the convenience to get information, and improve discipline. Subjective Norm (SN) variable has three indicator that influence the behavior in the use of systems and parties are important in the use of the system. Attitude Toward Using (ATU) variable has indicators, such as in the form of his attitude towards the implementation, in the spirit of the task, the variable of User Satisfaction (SAT) has covering his satisfaction, the work load becomes lighter, and improved performance in the task. Behavioral Intention (BI) has indicators, such as motivation to keep using, plan to keep using the future, motivating others to use, the motivation to provide inputs for use. Variable Actual Usage (AU) uses his intensity indicator use in completing the task, the accuracy of the information in the HIS, the reference of the information in the HIS, and the availability of a complete application in HIS.

\section{Result and Discussion}

\subsection{The Development of the Theory-Based Model}

In the study Tabibi et al. [7], Mandatories of system use (Mand) variable has no significance influence with other factors, so that this variable was not used. Referring to the previous studies, the factors that affect the TAM in the information system of hospital management to pay more attention to users. The variables are Subjective Norm, 
User Satisfaction, Perceived Ease of Use, Perceived Usefulness, Behavioral Intention, and the Actual System Usage) $[5,7,9,12$ - 14].

From the scheme, it can be formulated hypothesis as follows:

- Hypothesis 1a: Subjective Norm affect Perceived Usefulness

- Hypothesis 1.b: Subjective Norm influence behavior Intention to Use

- Hypothesis 2.a.: User Satisfaction affect Perceived Ease of Use

- Hypothesis 2.b.: User Satisfaction affect Perceived Usefulness

- Hypothesis 3: Perceived Ease of Use affect Perceived Usefulness

- Hypothesis 4.a.: Perceived Usefulness affect Attitude Toward Using

- Hypothesis 4.b.: Perceived Ease of Use affect Attitude Toward Using

- Hypothesis 5 : UsingAttitude Toward affect Behavior Intention to Use

- Hypothesis 6 :Behavior Intention to Use affect Actual System Usage

Subjective Norm (SN) is a person's perception or assumptions about other people's expectations of certain behaviors that will do or will not do. Subjective norms also influenced by beliefs [15]. If an individual has a strong belief that the reference is important for them to do or not to do.

Perceived Ease of Use (PEOU) is something where the ease, freedom in the use of a system, in this case the computer. Ease can be seen from the intensity of technology use between user and the system. So it could be stated that the system is more often used to show the system is better known, is easier to operate and easier to use by users. Perception of usefulness (PU) is defined as a measure of where the use of a trustworthy technology will bring benefits to those who use it. Attitude Toward Using the TAM conceptualized as an attitude towards the use of the system in the form of acceptance or rejection as an impact when someone is using a technology called a jug in her job or user attitude towards the use of technology.

Behavioral intention refers to the behavior of individuals that have the intention or desire to do so. Behavioral Intention to Use (ITU) is the behavioral tendency to continue to use a technology. The interest can be seen from the use of a computer technology to the user so that attitudes, interests predictable.
Actual System Usage is the real conditions of use of the system. Such measurements as the amount of time spent using these technologies. A person will be satisfied to use the system if it believes that the system is easy to use and increases productivity.

\subsection{Develop Path Diagram}

The theoretical model on Modified Technology Acceptance Model which has been built in the first phase and then depicted in Path Diagram to do the estimation process by using AMOS. The theoretical model can be seen in Figure $5 \mathrm{a}$.

\subsection{Choose the Input Matrix for Data Analysis}

Analysis of the data will be done by using a maximum likelihood estimation of the model gradually. The first is the estimated measurement models by using Confirmatory Factor Analysis. Next is Structural Equation Model with a full analysis of the model to test the suitability of the model and causality in models tested.

\subsection{Model Identification and Criteria for Assessing Goodness of Fit}

There are 235 questionnaires that were returned and analyzed decent outlier data found as many as 28 data, so it can be used 207 data. This amount is sufficient to be able to use the software AMOS in its analysis. Identification of the model is done by using test Confirmatory Factor Analysis for the overall model or full structural models. On early models show the results of the model does not fit the model so necessary modifications. After the modification of the model obtained the final model (Figure 5.b.) where Chi-square amounted to 482.999 , the value of probability on this analysis shows the value of 0.00 . Another value of Goodness of Fit shown by GFI (0842). It is approximately 0.90 within the tolerance value. Similar with the value of RMSEA (0.079) under 0.08 so the model is considered fit with existing data. So that the model can be accepted. A good model is influenced by the construct validity and reliability indicators, too. In this case all the data is valid and reliable.

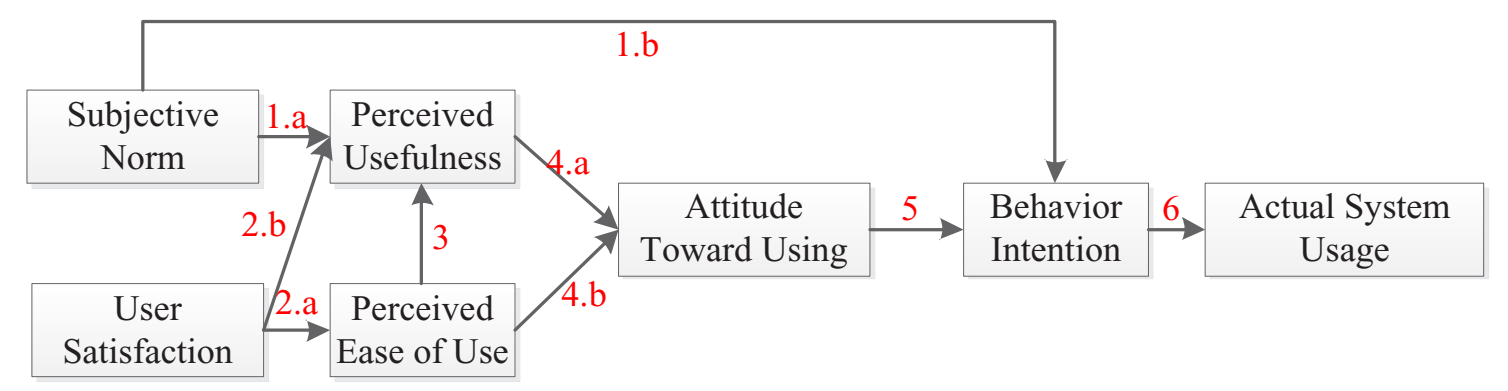

Fig 4. Modification Technology Acceptance Model Proposed on Selected Hospital in Sleman, Daerah Istimewa Yogyakarta, Indonesia 


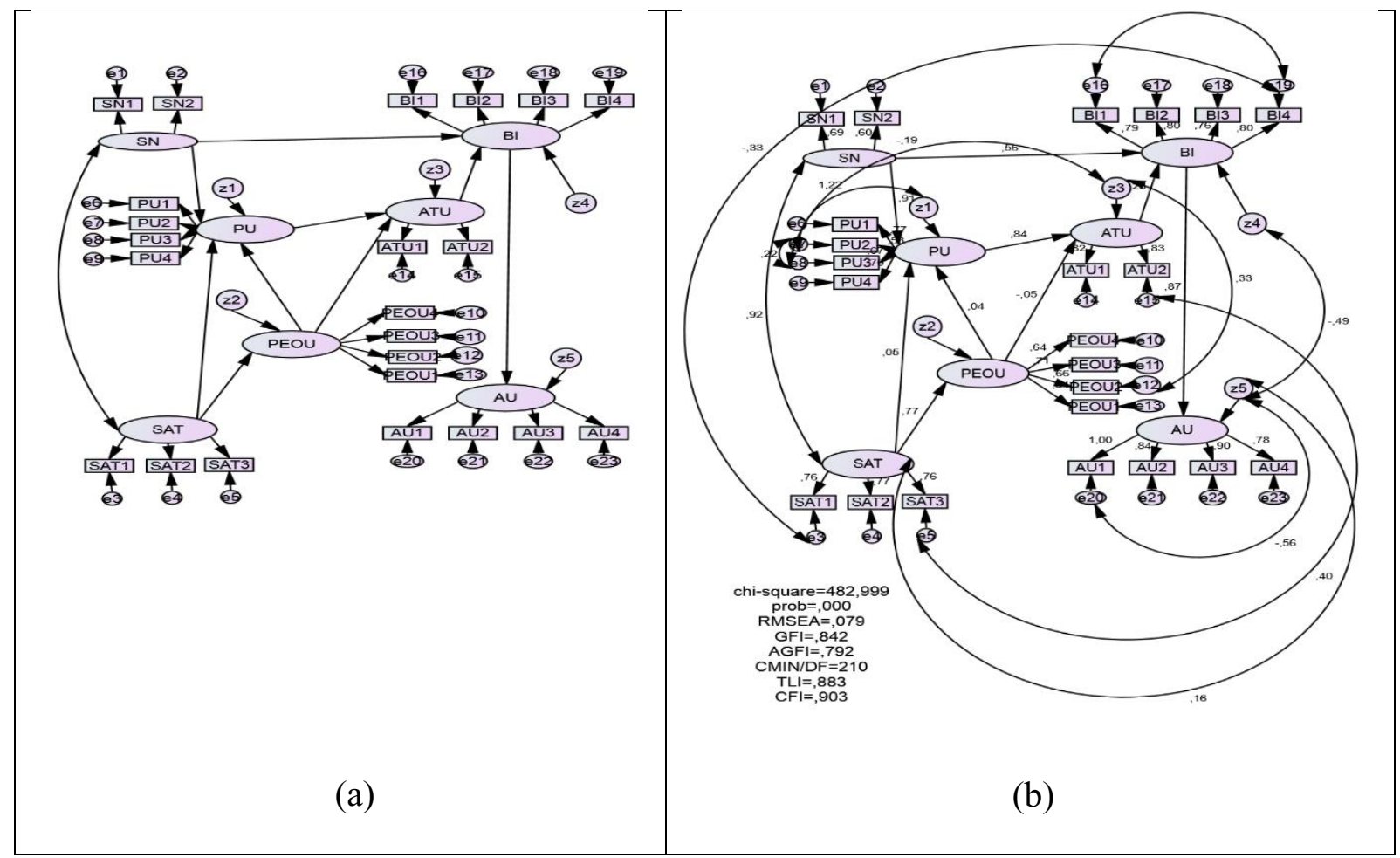

Fig 5.a. Early Path Diagram Model

Fig 5.b. Modified Path Diagram Model

\subsection{Interpretation of the Model}

After going through some testing, the last step is to conclude testing of hypotheses developed in this study. Value standard used which indicates that the hypothesis is accepted is by looking at the value $t$ count $>t$-table. Hypothesis testing is done by analyzing the value of CR and the probability values $(\mathrm{P})$, then compared with the required statistical limits, for the example above 1.96 for the value of $\mathrm{CR}$ and above 0.05 for the $\mathrm{P}$ value.

Hypothesis testing results show six accepted hypotheses, namely the hypothesis 1.a., the hypothesis 1.b., the hypothesis 2.a., the hypothesis 4.a., the hypothesis 5, and the hypothesis 6 . The rejected hypotheses are hypothesis 2.b., hypothesis 3, and hypothesis 4.b. It means that the acceptance of technology Hospital Information System strongly influenced by perceived of usefullness. Thus the managers, developers, and software metric coordination should fully understand to the benefits of HIS's application. Thus they can encourage the user to adopt it [8]. Without support from all hospital stakeholders, the use of the application can not run optimally.

\section{Conclusion}

Modified Technology Acceptance Model (TAM) can be used to evaluate Hospital Information System (HIS). From this research, it is found that the factors that may influence the user in using HIS are Subjective Norm (SN), Perceived Usefulness (PU), Perceived Ease of Use (PEOU), User Satisfaction (SAT), Behavior Intention to Use (BI), Attitude Toward Using (ATU), and Actual
System Usage (AU). Subjective Norm variable has a positive and significant relationship to Perceived Usefulness and Behavior Intention to Use. User Satisfaction variable has a positive and significant relationship to Perceived Ease of Use, but not with Perceived Usefulness. Perceived Ease of Use variable has an unfavorable and insignificant relationship to Perceived Usefulness and Attitude Toward Using.Good relationship occurs from Perceived Usefulness to Attitude Toward Using, followed by Attitude Toward Using to Behavior Intention to Use, and Behavior Intention to Use to Actual System Usage. Further research is to improve theories and models in other hospitals and in other fields, such as social, economics.

\section{References}

1. E. Hariana, G.Y. Sanjaya, A.R. Rahmanti, B. Murtiningsih, E. Nugroho, Penggunaan sistem Informasi manajemen rumah sakit (SIMRS) di DIY, Seminar Nasional Sistem Informasi Indonesia (2013)

2. Sabihaini, Analisis Pemanfaatan Teknologi Informasi dan Kinerja Individual (Studi pada Rumah Sakit di Yogyakarta), Jurnal widya manajemen dan akuntansi, vol.6 no.1, April 2006: 1-16 (2006)

3. E. Kristianto, Evaluasi Penerapan Sistem Informasi Manajemen Rumah Sakit di RSUP Dr. Sardjito Yogyakarta Dengan Menggunakan HOT-Fit, Unpublished Thesis, Magister Teknologi Informasi, UGM, Yogyakarta (2007)

4. A.B. Saputra, Evaluasi Faktor-Faktor Kesuksesan Implementasi Sistem Informasi Manajemen Rumah 
Sakit Di RS PKU Muhammadiyah Sruweng Dengan Menggunakan Metode HOT-Fit, Unpublished thesis, Magister Teknik Informatika, UII, Yogyakarta (2013)

5. E. Saputra, Misfariyan, Analisis Penerimaan Sistem Informasi Manajemen Rumah Sakit Umum Daerah Bangkinang Menggunakan Metode Technology Acceptance Model (TAM), Jurnal Sains, Teknologi dan Industri, Vol.10 No.2 (2013)

6. A.Ng.C. San, C.J.Yee, The Modified Technology Acccepetance Model for Private Clinical Physicians : A Case Study in Malaysia, Penang, Int.j. of academic research in business and social sciences, vol 3 no.2, ISSN : 2222-6990 (2013)

7. S.J. Tabibi, A.A. Nasiripour, R.B. Kazemzadeh, A.A. Farhangi, P. Ebrahimi, Effective factors on Hospital Information System Acceptance : A confirmatory study in Iranian Hospitals; Middle-East Journal of Scientific Research 9 (1): 95-101, 2011, ISSN 19909233 CIDIOSI Publications (2011)

8. L.G. Wallacae, S.D. Sheetz, The adoption of software measures : a technology acceptance model (TAM) perspective, Int.J. of Information and Management 51, 245-259 (2014)

9. M.Chuttur, "Overview of the Technology Acceptance Model: Origins, Developments and Future Directions ," Indiana University, USA . Sprouts: Working Papers on Information Systems, 9(37). http://sprouts.aisnet.org/9-37 (2009)
10. V.P. Anggelidis, P.D. Chatzoglou, Using a modified technology acceptance model in hospital, Int. J. of medical informatics, vol.78, issue 2, pp.115-126 (2009)

11. Menkes, Peraturan Menteri Kesehatan Republik Indonesia nomor 82 tahun 2013 tentang Sistem Informasi Manajemen Rumah Sakit, Jakarta (2013)

12. Han, Shengnan, Individual Adoption of Information Systems in Organisations: A Literature Review of Technology Acceptance Model, Turku Center for Computer Science Technical Report No 540 (2003)

13. B. Dharmarajan, K. Gangadharan., Applying Technology Acceptance (TAM) model to determine the acceptance of Nursing Information System (NIS) for Computer Generated Nursing Care Plan among nurses, Int. J. of Computer Trends and Technology (IJCTT), Vol. 4 Issue 8 (2013)

14. F.I. Yunastiti, Z.Baridwan, Penerimaan Individu Terhadap Sistem Informasi Berbasis Komputer: Pendekatan Modified Technology Acceptance Model (TAM), Jurnal Ilmiah Mahasiswa FEB Universitas Brawaijaya, Vol.2. No.1 (2014).

15. Dreana, M.Tirza. Analisis Faktor-Faktor Yang Mempengaruhi Penerimaan Penggunaan SIMAWEB Di Fakultas Ekonomika Dan Bisnis Universitas Diponegoro: Integrasi TAM Dan TPB, Unpublished Thesis, Fakultas Ekonomika dan Bisnis, UNDIP, Semarang (2012) 